\title{
Views of German Producers on > Teutonic< Metal: Production ApProaches and Generational EfFEcts
}

\author{
Jan-Peter Herbst \\ Introduction
}

Labels associated with a cultural or geographical origin are nothing new in rock music. When British rock bands such as The Beatles, The Rolling Stones, The Animals and The Kinks stormed the US charts in the mid-1960s, this phenomenon became known as the »British Invasion «. The late 1960 s to early ' 70 s gave rise to "krautrock «, an experimental form of German rock music, whose name was coined by the English radio DJ John Peel, who used it interchangeably with 'Teutonic rock (Herbst 2019b). In 1979, the British journalist Geoff Barton introduced the term +New Wave of British Heavy Metal< (NWOBHM) to describe the considerable number of British metal bands with a relatively coherent sound that differed from US metal. In the 1980s, metal spread from Britain and the USA to Central Europe and Japan. Over time, geographically associated labels emerged around the globe, such as >Viking metal for Scandinavian bands (Heesch 2010) or -Mesopotamian metal for artists from the Middle East (Pichler 2017). German bands introduced a different take on the genre, which became known as 'Teutonic - metal (Elflein 2017; Herbst 2019b, 2020a).

The relatively young discipline of metal music studies had a strong interest in metal from various parts of the world from the very beginning. Most of the research followed a socio-cultural or ethnomusicological tradition (Brown et al. 2016; Wallach/Greene 211). Even if titles such as Sounds and Origin in Heavy Metal Music (Karjalainen 2018) suggest that they deal with the sonic domain of the genre, this is rarely the case. Most research on geographically labelled metal genres tends to focus on stage presentation, music videos, artwork (Heesch 2010; von Helden 2015), historical storytelling (Pichler 2017) or lyrics (La Roca 2017). 
This chapter is part of a larger research project dedicated to >Teutonic metal, a style of music that has received relatively little academic attention so far. Elflein (2017) tracked the emergence of early German metal bands per city and region, while Herbst (2019b) examined stylistic features of German power metal, analysed >Teutonic s stereotypes in 400 years of popular music history (Herbst 2020a), compared the production aesthetics of metal from Germany, Great Britain and the USA (Herbst 2020b), and studied strategies of early German metal bands to become internationally successful (Herbst 2020c). Other research on sTeutonic rock includes national signification in the imagery and songs of Rammstein (Burns 2008) and Rammstein's representation of the Berlin Republic (Kahnke 2013).

Based on extensive interview material from five internationally renowned German metal producers, this chapter explores the views of these professionals on the >Teutonic metal label. More specifically, it examines what the label means to them and how it may influence their production practices, focusing on selected areas of production such as systematic recording approaches, choice of equipment, guitar and drum recordings and studio acoustics. In contrast to previous research by the author, this current investigation places more emphasis on generational effects by comparing three important producers from the early years of German metal with two younger producers of international standing. The focus is on production as well as on the producers' work experiences and attitudes. Musical characteristics of >Teutonic metal are only of secondary interest. ${ }^{1}$

Harris Johns (*1950) was the main producer of Noise Records, which made him known as the producer of >Teutonic < thrash (Kreator, Sodom, Tankard, Assassin). He also produced renowned heavy metal bands such as Helloween and Grave Digger. His portfolio of productions with foreign bands includes Sepultura (BRA), Krisiun (BRA), Immolation (USA) and Enthroned (BEL). Siegfried >Siggi< Bemm ( ${ }^{* 1956)}$ ) was the main producer of the early Century Media label. He produced major thrash and death metal bands from Germany (Angel Dust, Kreator, Morgoth) as well as international acts like Tiamat (SWE), Moonspell (PRT), Rotting Christ (GRC), Theatre of Tragedy (NOR), Therion (SWE) and Samael $(\mathrm{CH})$. Karl >Charlie< Bauerfeind (*1963) worked closely with the record label Steamhammer, for which he produced many of the internationally recognised German melodic speed metal bands (Helloween, Gamma Ray, Running Wild, Blind Guardian, Rage) and foreign bands such as Motörhead

1 For example, for Anglo-American audiences, the German vocal accent was an obstacle for many early German metal bands (Herbst 2019b, 2020c), as were performances that were often perceived as stiff in line with common stereotypes (Herbst 2019b; Herbst/Bauerfeind 2020). 
(UK), Saxon (UK), Venom (UK), Rob Halford (UK) and HammerFall (SWE). The younger generation of metal producers was covered by two professionals. Lasse Lammert (*1980) has an international portfolio that includes Gloryhammer (UK), Alestorm (UK), MessengeR (GER), Svartsot (DEN), Inner Sanctum (IND), Rumahoy (UK) and The Atlas Moth (USA). Sebastian >Seeb Levermann (*1981) became known as founder, lead singer, guitarist and producer of the thriving metal band Orden Ogan. In recent years he has produced several high-profile German bands (Brainstorm, Almanac, Grave Digger, Heaven Shall Burn) as well as international acts like Rhapsody of Fire (ITA), Pectora (DEN), Cremisi (ITA), Riot V (USA), Armored Dawn (BRA) and Vanishing Point (AUS).

Methodologically, the study follows a qualitative design in the young tradition of Interpretative Phenomenological Analysis (IPA) in research on recording professionals (Martin 2014; Thomas 2015). In contrast to qualitative content analysis or grounded theory, IPA rather intends to »explore the participant's view of the world and to adopt, as far as possible, an sinsider's perspective of the phenomenon under study « (Smith 1996: 263f.). This method mitigates subjective (mis-)interpretation, as respondents describe their experiences in their own words, so that the study remains closely linked to its primary source. Therefore, a larger number of translated producer quotes from a pool of over fifteen hours of interview material is used for analysis.

\section{The > Teutonic label and music}

The term >Teutons has been applied to different groups and phenomena for almost two millennia, which is why its use and meaning vary in different contexts. It first appeared in the late second century BC. The Teutons were a tribe from Jutland, today's Southern Denmark and Northern Germany. Attacks on the Roman Republic gave them the name Furor Teutonicus (>Teutonic Fury<). Even though the tribe has long disappeared and no direct line of descent between Teutons and Germans can be drawn, the name has remained as a synonym for Germans (Kerr/Wright 2015: 655). The area that is now Germany was governed by various authorities between 800 and 1866: the Carolingian Empire, East Francia, the Kingdom of Germany (Latin: Regnum Teutonicorum), the Holy Roman Empire and the German Confederation. In 1871, the German Empire (1871-1918) was founded, which included most of the German states as well as several duchies that today belong to Germany and France. The two German-speaking countries Switzerland and Austria did not belong to the German Empire, yet they are sometimes listed under the >Teutonic label. For example, an article in Metal Hammer magazine entitled 
>Teutonischer Tod [ [Teutonic death] defines the >Teutonic < area in modern metal as Germany, Austria and Switzerland (Schürer 2009).

In music history, there are frequent references to >Teutonic music and its peculiarities in the perception of a foreign audience (see Herbst 2020a). With respect to performance idioms, instrumentation and sound ideals, >Teutonic - music already differed from Italian and French styles in the $17^{\text {th }}$ and $18^{\text {th }}$ century through its mixture of French >delicacy< and Italian >vitality (Lawson/Stowell 1999: 42-44). In the early 19 ${ }^{\text {th }}$ century, few people portrayed the Austro-German style as stereotypically as the composer Felix Mendelssohn. His rigidity in tempo and ensemble synchronisation earned him a reputation in the English-speaking world as the successor to >Teutonic composers like Haydn, Mozart and Beethoven (Brown 2003: 388). Richard Wagner is attributed an even greater influence on sTeutonic b bands from Germany and abroad (Herbst 2020a). With the Neue Sachlichkeit (new objectivity) movement after the First World War, the international image of >Teutonic music lasted on. Rigidity and rationality through the deliberate renunciation of lush idioms of Romantic music were emphasised even more strongly (Hill 1994: 39). This aesthetic was taken up by the German avantgarde group Kraftwerk, which portrayed itself as »man-machines « (Adelt 2016: 23; Nye 2013), characterised by, in the words of band member Ralf Hütter, a »Teutonic rhythm, really Germanic « (Barr 1998: 142). Several years later, rock bands were labelled >Teutonic < by the foreign press because of their precise and rigid performance (Herbst 2020a). A frequent use of the >Teutonic label can be found in one of the earliest and most influential rock and metal magazines, the British Kerrang! (since 1981). For example, in 1986 Accept were labelled »Teutonic titans « (Kerrang! 1986: 6), and their music was described as »very Germanik - by that I mean marching riffs played intensely! « (Russell 1991: 54). In Germany the term >Teutonic « was not very common in the 1980s and '90s, although the Rock Hard magazine released the samplers Teutonic Invasion part I (1987) and part II (1988) in cooperation with the Dutch label Roadrunner in the late 1980s. Since the 2000s, the term >Teutonic < has been used more frequently in German metal magazines, mostly to denote a style of heavy metal in the tradition of Accept (Stappert 2004: 92). As an interview study (Herbst 2019b) with German metal producers, musicians and journalists suggests, the German scene usually differentiates between the terms > German< and >Teutonic < metal. Whilst >German< metal refers to progressive metal bands such as Helloween and Blind Guardian, 'Teutonic < denotes backward, simple, unrefined and rhythm-focused metal in the style of Accept, Running Wild and Grave Digger. 
Sean Nye (2012) argues in his essay »What is Teutonic? « that the label is not referring to an artistic style, but rather to a complex aesthetic that encompasses a variety of ideologies. It was commonly used as a synonym for everything Germanic in nineteenth century England and caused anxiety about the rise of Wilhelminian Germany and the associated fear of a strengthened united Germany, which became a dangerous rival of the British Empire (Nye 2012: 116). This threat was not only of a purely militaristic and industrial nature (Nye 2013: 20ff.), but also cultural due to the international popularity and influence of Austro-German classical music (Nye 2012: 119). The Prussian military power and finally the Second World War increased the level of threat, and so the British and Americans used the term >Teutonic in their war propaganda to designate all evil in Germany (ibid.: 120). Nye argues that although these events took place several decades and centuries ago, the term >Teutonic is still used in the Anglo-American world; no longer in the form of a demonization of Germany, but as a trope that »articulates a range of fears and anxieties about its own political and cultural position in the world since 1945 « (ibid.).

Such uneasiness with German culture and music has been well documented in recent centuries. Carl Maria von Weber's Freischütz (1821) was perceived as »a typical product of the Teutonic romantic movement ... [which] leaves a modern Anglo-Saxon audience, alas! Cold« (Williams 2008 [1932]: 415) and Richard Strauss's Feuersnot (1901) was »too Teutonic « (A.K. 1902: 808) for a British audience. In the early days of German rock and metal, the vocal sound of the Scorpions was described as "clipped Teutonic tones « (Johnson 1986: 28), Grave Digger were ridiculed as »toxic Teutons « (Barton 1986: 8) and Destruction as a »titanic, Teutonic monster« (Johnson 1987: 15). These selected examples show the frequent use of the adjective >Teutonic<, which suggests the continued unease with Germany's militaristic and imperialistic past. This is consistent with the widespread use of the WWII term »kraut « in metal reviews (e.g. Russell 1986: 22). The unease with Germany is further illustrated by common expressions such as »Don't mention the war. Don't mention the war ... « in interviews with German metal bands in the 1980 s, which continued into the late 1990s, for example in connection with Rammstein, exacerbated by their lack of command of the English language and their awkward relationship with the media in their early years (Fortnam 1998: 40). ${ }^{2}$ The language barrier has often contributed to the awkwardness

2 Rammstein were perceived as militaristic by both British and US-American audiences. The Washington Post wrote, »With jackboot rhythms and plenty of Teutonic rage, the sextet ... marched out of Germany in 1993 and has been blitzkrieging charts around the globe« (Segal 2001), and Kerrang! described their 
of the British audience and journalists towards German metal bands, not only in interviews and communication with live audiences, but also in the lyrics and vocal accents that often put off Anglo-American audiences (see Herbst 2020c). Given these negative connotations, it is hardly surprising that the German media did not use the label >Teutonic < until the 2000s, when it became less common in foreign media or at least lost its sometimes harsh and disparaging undertones (e.g. Dome 1986; Van der Kirkhoff 1993). Similarly, many German bands rejected the >Teutonic < label in the 1980s and ' 90 s because of its stereotypical and condescending associations, but later some adopted it as a trademark for style and heritage. For example, in 2010 Accept released the song »Teutonic Terror « and produced a music video for it. Curiously enough, some bands that deliberately played with German stereotypes like Accept and Rammstein became internationally successful, while those that unintentionally came across as > Teutonic such as Running Wild and Rage were mocked for this aesthetic (Herbst 2020a, 2020c). In summary, Nye (2012) sees the 'Teutonic < less as a distinct musical or aesthetic style than as a self-reflection of Anglo-Americans through their rival Germany, which »articulates a range of fears and anxieties about [the Anglo-American's] own political and cultural position in the world since 1945« (Nye 2012: 120). This concern about industrial and militaristic strength is reflected in the foreign metal media that portray German bands as effective, industrial, dangerous, and a potential threat. In the German metal scene, however, >Teutonic generally refers to a specific style of traditional heavy metal that is characterised by conservatism and simplicity (Herbst 2019b). Yet for some metal musicians like Blind Guardian, >Teutonic « metal is a »way of life«, as their producer Charlie Bauerfeind revealed.

Because of this flexible understanding of the term, it was not defined in the interviews with the producers. The aim was rather to determine the personal understanding and relevance of the term for each producer.

In accordance with the variety of understandings and associations with the >Teutonic metal label, the views differed, though less in terms of age. Only Bauerfeind defined himself as a >Teutonic p producer. He has a clear idea of how >Teutonic metal should sound like, a concept he began to develop while studying music production in the USA in the mid-1980s. It was there that he became aware of cultural differences between the USA and Europe and the impact these differences have on musical practices (see Herbst/ Bauerfeind 2020). Nevertheless, Bauerfeind adds a >Teutonic signature to each of his productions, regardless of the artists' origins. This signature would

sound as »of a thousand marching footsteps. Predictable, certainly, but as devastatingly effective as a Volkswagen up the $\operatorname{arsch}$ « (Everley 2001: 44). 
make the outcome predictable and meet the expectations of the target audience for >Teutonic metal, which is after all one of the main reasons why bands and record labels hire him. But this somewhat inflexible sonic signature has also caused problems in his work history. In the music business, bands sometimes collaborate with a producer chosen by their label, which can lead to conflicts due to deviating sound aesthetics. This happened when Bauerfeind produced the British proto black metal band Venom for the German label Steamhammer. By improving ensemble synchronisation and overall playing precision through audio editing, he removed the sloppy raucousness characteristic of the band, and this did not please the artists. They demanded Bauerfeind to undo the editing to keep the performances raw. In another case, after four albums produced with Bauerfeind, the NWOBHM veterans Saxon hired British producer Andy Sneap to return to their looser rock'n'roll sound. However, there were others, the Swedish HammerFall and Brazilian Angra, who decided to work with Bauerfeind because they associated his >Teutonic signature with popular German bands like Gamma Ray (Herbst/ Bauerfeind 2020).

Johns was well aware of the journalistic label >Teutonic thrash, and being considered its most renowned producer makes him proud. But when asked what he thought about the label, he replied:

»It means little to me. ... Labels always came last with me, I only learned about them afterwards. It didn't interest me at all. For me it was always individual bands. That they were eventually summarised to a term, well, sure, it makes it easier to classify them, if you must classify them, but for me there was no reason to classify them « (Interview Johns 2018).

Despite personally rejecting the label, Johns has capitalised on his reputation as a >Teutonic < thrash metal producer and continues to do so to this day.

Bemm, the third veteran producer, questioned the usefulness of the term even more than Johns:

»I don't understand >Teutonic metal, just as I don't understand the various subgenres of metal ... The term >Teutonic « metal, okay, we are >Teutons we make loud noise. The Americans have done it and the British too; the Finish in any case. Therefore, >Teutonic metal puzzles me, and when I listen to Helloween, I wouldn't know they are a German true metal band. They could be an English or American band just as well. ... What is >Teutonic $<$ metal, I don't know?! >Teutonic « metal is metal (Interview Bemm 2017).

He rejects the journalistic practice of classifying metal primarily because conforming to certain expectations restricts artistic freedom. 
Having graduated from a music production course in the USA, Lammert does not advertise a >Teutonic style to his clients. Sometimes his origin is advantageous for him, for example when he works with foreign bands that are inspired by >Teutonic - metal. He recalled a production with the Scottish Gloryhammer, who deliberately sang wrong English with a fake German accent to pay tribute to their idols (Herbst 2019b). In most cases, however, Lammert is hired for his professional service and production quality, which is based on international standards. He dislikes restrictions such as national genre labels like Johns and Bemm, as they all value the traditional role of the producer as a creative director trying to find the best sound for each band.

For Levermann, labels like >Teutonic < are merely a journalistic necessity. He refuses to classify his band Orden Ogan as >Teutonic metal, partly because he sees little use in labels in general, and partly because his band's inspirations and style are not limited to German music. As a producer he does not believe that he has a particularly >Teutonic s style. He started in 2013 and immediately worked digitally >in the box<, as opposed to a traditional analogue console and outboard equipment. As an autodidact, he has been inspired internationally by reading production resources on the Internet and listening to a variety of music. In addition to international competitiveness in terms of sound quality, the producer's personal style is most important to him. German and international bands would hire him for these attributes. Furthermore, he believes that it is important to trust one's own ears and gut feeling and not to worry about rules. In his experience, mythology and idealised production approaches are widespread in the recording business, although the perceptions often diverge strongly from reality. He believes that what producers, bands and audiences might perceive as >Teutonic does not necessarily correlate with what was done during the recording and production of an album. Most importantly, Levermann does not want to impose his style on the sound of the band. He gives professional recommendations but is also willing to learn from bands. After all, every band and production is different, so there cannot be the one and only approach that always works.

Despite the different views on the label, most of the producers shared some common understanding of the bands they consider >Teutonic<. The origin of these associations goes back to the 1980s and early ' 90 s, when there was only heavy and speed metal. Speed metal eventually split into thrash metal and power metal. The German thrash bands Kreator, Sodom, Destruction and Tankard eventually became known as the >Big Teutonic Four<, the German equivalent of the four big American thrash bands Metallica, Slayer, 
Megadeth and Anthrax (Lusty 2020: 168). ${ }^{3}$ For German heavy and power metal the associations are more complicated. While the success of bands such as Helloween, Gamma Ray and Blind Guardian has given audiences abroad a sense of German metal, most German metal fans as well as Bauerfeind, Lammert and Levermann consider bands in the tradition of the German pioneers Accept to be stereotypically >Teutonic «, Running Wild and Grave Digger above all. These bands are at the traditional end of the scale; more innovative bands like Helloween are less considered >Teutonic < by fans and the producers interviewed. The foreign perception, as seen in metal journalism (Herbst 2020a, 2020c), has rarely differentiated between innovative and traditionconscious German bands. Cohen (1985), Anderson (1983) and Hobsbawm/ Ranger (1983) have argued that societies are constructed symbolically through myths and invented traditions as an »imaginary community « to define values and cultural practices. It seems that foreign audiences find it difficult to distinguish between different kinds of German bands, so that they have often uncritically classified most of them as >Teutonic <. For the German audience and music professionals, there are different scenes within German metal with diverging symbolic boundaries and values; scenes based on more traditional bands are rather considered >Teutonic . Bauerfeind confirmed that German record labels and bands are aware of these markets and target them specifically. He encountered several productions where labels approached him to produce a band because their previous album did not meet the expectation of the scene and had failed commercially because it was selfproduced or done with a foreign producer (see Herbst/Bauerfeind 2020).

Foreign media have often perceived metal from Germany as stale and antiquated (Herbst 2020a, 2020c), as a Kerrang! review of Running Wild's Death or Glory (1989) illustrates:

»Well produced and featuring some classy musicianship, >Death Or Glory< is nevertheless nothing new nor above average. Sub-Iron Maiden Metal, every-

3 Compared to more traditional German heavy metal bands, German thrash metal bands were generally perceived more positively in the UK and the US. As a result, they were far less likely to be labelled >Teutonic<, suggesting that the label was most often used in a derogatory manner (Herbst 2020a). The term >Big Teutonic Four seems to be relatively new. It was used on a four-track $C D$, enclosed with the January issue of the German Legacy magazine (01/2013), that was entitled >Big Teutonic Four . One month later, Nuclear Blast released a sampler with almost the same track list and with the same title (Otto 2013). Thereafter, the term was taken up in other German metal media (e.g. Anonymous 2013) but used far less in foreign media. This indicates that although the global reputation of German thrash metal from the 1980s and ' 90 s is undisputed, the term >Big Teutonic Four is mainly used in the German discourse, possibly for marketing purposes or to express pride in the international success of German thrash metal. 
thing at the gallop, an occasional nod in the Thrash direction, dusty old chord sequences with their origins in the mists of time, an overdose of >stirring raised-clenched-fist melodies that regularly throw up strangely folksy, Gary Moore-like Celtic overtones as well as the typically well dodgy Germanic strains ...« (Henderson 1990: 26).

Other examples include a review of Victory's Temples of Gold (1990), „mediocre. At best the band achieve something spirited and competent. At worst it is simply laboured « (Watts 1990: 26), or of Sargant Fury's Still Want More (1991), »Germany appreciates precision. German hard rock is regimented, clinical and exact. As a result of that, it isn't usually very good (Watts 1992: 21). Most German metal bands were perceived either as imitators of British and US-American bands or as followers of established styles and not as innovators (Herbst 2020c). Therefore, the use of the >Teutonic label in foreign media can be distinguished in three ways: Firstly, as a general, tongue-incheek description for all German metal bands; secondly, to describe those German bands that are perceived as conservative and boring; thirdly, and often in connection with the second point, to designate bands that appear particularly German because of their vocal accent, their idiosyncratic lyrics and their performance and show characteristics, as they correspond to foreign stereotypes. This is reflected in a Kerrang! review of Thunderhead's Behind the Eight-Ball (1989) album, which benefitted from the fact that an USAmerican singer was featured on it: "impressive for a first effort, with a number of cracking songs and a distinct lack of that peculiarly Germanic feel that has been the stumbling block for many German bands « (Henderson 1989: 48). The extent to which the foreign media have deliberately chosen one of these three meanings is unclear and requires further investigation.

Recently the Rock Hard magazine published a special on German metal. Considering the defining criteria for metal from Germany, Heaven Shall Burn guitarist Maik Weichert in his article reflected:

»Is German metal a style? In some cases, not really, is it? But it can't be just the origin either, after all you recognise immediately when for example Hammerfall pay homage to the holy Accept. Is there such a thing as a self-image, a sense of tradition? The eternal luck that Gamma Ray will always sound like Gamma Ray and Running Wild will always sound like Running Wild? Reaction instead of innovation? Many people see this as the great strength of German metal. Who wants an experimental Grave Digger record or vocal innovations by Udo Dirkschneider [of Accept]? Exactly. And this is exactly where we are exploring a very important aspect. The common German metalhead is strictly conservative, almost reactionary. That's not meant to be negative at all. The German metal fan represents the shepherd dog of the metal world. Loyal, if everything 
is as usual, and hellishly aggressive if something is too unusual or if you want to conceal a lack of quality with cheap tricks. But this is exactly what creates an environment that promotes perfection rather than innovation« (Weichert 2015: 14; my translation).

The view expressed by Weichert is in line with the producers' statements. All producers except Bauerfeind do not like to be classified as just a >Teutonic producer because they neither want to be conservative nor accept a restriction of their creative freedom. Even Bauerfeind admitted to feeling increasingly restricted by the label. For this reason, he explored the implementation of foreign cultural elements in a >Teutonic production aesthetic with Helloween. One experiment involved recording drums without a click track whilst keeping drum and ensemble performances highly synchronised, as required for a >Teutonic a aesthetic (see Herbst/Bauerfeind 2020). To add a -South American< feeling, he layered in percussion loops from Heavyocity Media (2019), especially the orchestral »Damage« pack. Such packs are often used in action scenes in movies and TV series to add suspension. By adding these loops, complementary rhythms to the strict >Teutonic rhythms (ibid.) were created by syncopation. For other, less progressive bands, however, Bauerfeind's productions tend to be more conservative and follow proven >Teutonic < recording and production practices (Herbst 2019b; Herbst/Bauerfeind 2020).

\section{Approaches to music production}

Relatively little research has focused on recording, mixing and mastering practices and their impact on the sound of particular regions and cultures. Meintjes' (2003) ethnomusicological investigation sheds light on the >Zulu sound of South Africa, whilst Zagorski-Thomas (2012) and Massey (2015: 1-14) examine British and US recording practices of 1960 s and ' 70 s soul music. In his handbooks, Owsinski deals with the mixing styles of major music cities such as Los Angeles, New York and London (2006) as well as various mastering practices on the east and west coasts of the USA (2008).

The three veteran producers belong to the small group of recording professionals with whom the main German metal labels worked together in the 1980 s and '90s. With their rock background, none of them were familiar with the foreign metal bands their clients listened to, most notably Metallica, Slayer, Iron Maiden and Judas Priest (Herbst 2019b). They studied the production work of their international colleagues to learn more about their practices, but they were keen to develop their own styles (see Herbst 2019b). 
A distinction between German and foreign productions concerns the use of equipment. In line with Zagorski-Thomas's (2012) finding that production resources began to standardise in the 1970s, German producers had access to similar technologies used by the British and Americans. Yet, certain conditions contributed to an original sound. According to Bauerfeind, Johns and Lammert, one of the main differences was the guitar sound, a fundamental and defining quality of metal and its subgenres (Herbst 2017). Guitar players agree that there are British and American guitar sounds (Stent 2019). Some of the associations are historical, as bands in the early years of rock music tended to play amplifiers from their own countries. To this day, there are sonic differences between British and American amplifiers, which result from the deviating circuit designs, types of valves, speakers and cabinets (Brosnac 2004; Herbst 2020b). In Germany, many early metal bands played amplifiers from the German manufacturer Engl (founded in 1983), a practice that, according to Bauerfeind, gave the bands a unique sound:

»The basic character [of the guitar sound] is determined by the amp, they all have different characters, Marshall, Engl, [Mesa] Boogie and so on ... And this is what shapes styles within metal, for example in melodic metal you have the even distortion of Engl amps. In more rock-based metal, you have Marshall sounds, which by far don't distort so evenly. ... British and American players liked the [Peavey] 5150, and Americans [Mesa] Boogie, of course. The [Mesa Boogie] Rectifier is the typical sound of America. And Germany is Engl for sure, it is Engl country, that's a trademark! Everybody in Germany was interested in sounding original, not sounding like everybody else internationally. This was easy to achieve because everybody who played Engl had a sound of their own, this was the >Teutonic « metal sound. Engl amplifiers were also extremely distorted. One of the most characteristic sounds was that of the Engl Straight model, every >Teutonic metal band played it. I know of Victory, Gamma Ray, Helloween, Kreator, everybody played it, they still do in the studio. Engl supported many bands, endorsed them all! But it's worth noting that when Engl changed management in the late '90s and replaced the Straight by the Savage model, the sound changed too. The classic >Teutonic < sound is that of the old Straights! (Interview Bauerfeind 2017).

Since production of the characteristic Straight model had been discontinued, Bauerfeind began using a sprofiling a amplifier to maintain his recording style. The German Christoph Kemper invented the profiling technology that makes it possible to capture the sonic fingerprint of any guitar amplification chain and authentically reproduce it (Herbst 2019a). It enables recording the original amplifier in a specific studio room thus capturing its acoustic environment without risking to wear out the precious old device. 
Thrash producer Johns confirmed the influence that Engl had on his productions. Before Engl became available, he used British Marshalls; later American Mesa Boogie Rectifiers and Peavey models become more common on the German market. With Engl's generous endorsement practice, their amplifiers quickly became standard in the studios and gave German productions an original sound: clean, defined, but more distorted than their American and especially British counterparts. Johns explained, however, that his main consideration was the required level of heavy distortion in the guitar sounds. This could be achieved with many devices when using boosting pedals. He fondly remembers experiments where, for example, a signal was routed through an Ibanez Tubescreamer overdrive pedal into a Vox AC30 amplifier, which then was connected to another Marshall amplifier. The production of unconventional signal chains was a practice that suited the more aggressive aesthetic of >Teutonic c thrash metal bands, as it created a more extreme guitar sound than that heard on American releases by the likes of Metallica and Slayer.

Bemm has no particular preference for specific guitar amplifiers or brands. He has a large collection of different devices and a professional network with a large number of models from which he chooses for each production, taking into account technical requirements and aesthetics, rather than cultural associations.

Lammert is internationally recognised as a guitar expert, selling his own signature sounds as packs for Kemper Profiling and Fractal Audio System Axe FX amplifiers (STL Tones 2019). Before the mid-2000s he had not worked professionally, but as a fan of early metal and with an interest in guitar sounds, his perception bears parallels to the experiences of Johns and Bauerfeind:

»Back then, there was the Engl Straight ... It was relatively cheap, and Mesa [Boogie] was hard to get. Kai Hansen, for example, had this Straight. And Kai Hansen played guitar in half of all German bands. He always played this amp and that's why he had a lot of influence. ... It's a classic German amp, until the mid to late '90s. It was used to record all that power metal and >Teutonic « stuff. ... The new Engl amps sound different, but they are still considered >Teutonic $<$. This has less to do with the sound, but I think it's more about German quality, where it comes from. The new Engl amps are very precise, sound very clean, and therefore have this German sound. But I think when you say, or what it says in the forums, German sound, there is nothing or no connection to the German metal sound, which was influenced by the old Engl Straight. So, when you read in the forums, Engl = German sound, I don't think they mean the >Teutonic metal sound, but the sound of modern German amps. You must look at them separately, I think, because the Engl that shaped the >Teutonic metal sound actually sounds completely different from the new Engl. ... Most 
of the new Engls have 6L6 valves and sound more American, I would almost say cleaner, more sterile. The Straight model used British EL34 valves and was more granular, slightly >Marshall in design. If you ask the forum user, German sound = Engl, he surely doesn't mean the German metal bands but just the modern Engl sound, which is very sterile and clinical« (Interview Lammert 2018).

This development of stereotypical associations is unusual because it contradicts the general development of production practice in metal music. As is argued elsewhere (Herbst 2019b, 2020a, 2020b), cultural and nation-specific musical features, which are reflected in recording practices and performance characteristics, have become less distinct since the turn of the millennium due to the establishment of digital music production and other effects of globalisation like access to the Internet and musical inspiration from around the world. In view of this development, the influential early metal bands from Germany should be perceived as more stereotypically >Teutonic sounding than newer productions in general and in terms of their guitar sound. It can only be speculated whether Engl's decision to replace the Straight model with newer devices that have more typically German qualities like clinical control was a deliberate marketing decision or not. The sterile sound, as Lammert describes it, corresponds to the centuries-old common foreign perception that German popular music is rigid and restrained (Herbst 2019b, 2020a, 2020c). It also accords with Weichert's (2015: 14) reflection of German metal sounding proudly German, which he regards as a quality seal, similar to German engineering.

Another stereotypically German approach to recording and production is apparent in Bauerfeind's systematic organisation:

»I have documented my work for decades ... At some point I started filming and photographing everything to have a repeatability in my work that my clients demanded of me. I had people who said two years later >I want exactly that, but with this and that deviation ‘. And as long as I can't return to the point of >but that<, the deviation is irrelevant. This documentation went so far that I was recording things in good faith that it was exactly as it was shown in the photos, only to find that out it wasn't because another cabinet was connected. So, I had the wrong mic, the wrong setup, the wrong amp, and then I corrected that because the customer wanted to go back to exactly where he was two years ago« (Interview Bauerfeind 2019).

Even though Bauerfeind shows in his reflection that documenting recording setups is not entirely possible, he meticulously keeps records of his productions, a practice that matches the German stereotype of exactness and thorough organisation. His German clients in particular expect this documenta- 
tion, as they want to be able to recreate sounds used on earlier records. This once again coincides with Weichert's (2015: 14) characterisation of German metal as »strictly conservative, almost reactionary«. While »staying true to your sound « is surely not unique to German metal, this seems very important for many German bands, and Bauerfeind is making considerable efforts to accommodate this request. The effort behind such productions becomes even clearer when considering that bands and their producers, according to Bauerfeind, used to record and mix in various studios to meticulously create their desired aesthetics:

"You used to go to certain studios, partly because of the acoustics of the room, but also because of the technology of the mixing console. You wanted to have a uniform sound. Today, someone opens his computer and then plugins are inserted. You can do that, no question, but these characteristics people have created have been lost. I can only speak about rock, but most people have recorded drums on transparent, glassy sounding consoles. They mostly used [British] Solid State Logic [SSL], they had an E Series. The SSL E series had specific filters. Over the years, they started changing the filters on the advice of their customers. There was an Orange EQ, a Black EQ, a Brown EQ, those were the colours of the knobs that were on those channel strips. And that's how preferences developed over the years, someone only wanted to do his bass drum with an Orange EQ etc. We used to record drums on an E Series because it sounds very fast, transparent and close, while we recorded guitars on a [SSL] G Series, whose filters had a smoky, rough sound. People deliberately went to certain studios because they knew which desk was standing around, because specific characteristics were desired.... A lot of people eventually went to the Neve [a British console] room to mix, because that had all the colourings and sound characters you wanted. The colouration got completely lost by all this plugin junk. Nowadays, there are thousands of plugins, and unfortunately, the characters are lost. It all sounds the same« (Interview Bauerfeind 2019).

This quote indicates why culture- or nation-specific sounds decreased over time and became less distinct. Bands had less budget to afford renting highly specialised studios and equipment. Instead, digital technologies standardised production approaches and made various tools available regardless of the original context to which they were linked, leading to a loss of their regional character (Herbst 2019b, 2020a).

When confronted with Bauerfeind's experience, Levermann was divided on the usefulness of such practices in modern business. Although he recognised the significance of Bauerfeind's work for early German metal music, he rejected such an inflexible production approach as mythologically motivated. Younger producers of the "generation mouse «, who did not experience the 
analogue days and the prosperous music industry of the past, had to work under completely different conditions and did not have the luxury of spending time and money on subtle sonic details. Moreover, Levermann felt that there are such a multitude of variables that influence the final sound that it makes little sense to him to recreate the recording conditions of past decades. Using the guitar as an example, Levermann explained:

»On guitar sounds there are so many different elements that shape the sound, the smallest of it is actually the amplifier head. ... There are so many factors, every millimetre you move the microphone will change the sound of the amp. The position of the cabinet in the room, the speaker in the cabinet, the cabinet itself, humidity. I'm always the guy who tries getting the best out of what is there. ... Well, in the end, everybody plays the same amps, and they all sound very similar anyway. Okay, [Mesa Boogie] Rectifiers sound a bit denser than a [Peavey] 5150, but all the modern metal amps sound so similar. ... Except for an old '70s Marshall which you recognise easily, but with all more modern sounds, especially if you have 7- or 8-string guitars, you really don't hear differences anymore. ... So, I just check if the amp fits to the music, it takes a lot of gut feeling. The direct signal must be clean« (Interview Levermann 2019).

Modern metal productions, even in more traditional subgenres like heavy metal, use such heavily distorted guitar sounds that are drastically processed later in the mixing phase. Therefore, subtle tonal variations between amplifiers are hardly of interest to Levermann, unlike Lammert, who displays a large collection of guitar amplification technology on his studio website (LSDStudio 2020). Apart from their different views on guitar recordings, the two younger producers, Levermann and Lammert, often work with bands remotely to save costs. The bands record their guitars and basses themselves and send the recorded direct injection (DI) tracks to the producer for re-amping to capture the final guitar sound. Since modern producers usually work in their own studio premises with their own equipment, the resulting sound matches the personal style of the producer. This means, however, that he/she has fewer options to adapt the sound to a certain cultural aesthetic than Bauerfeind. Access to studios is probably one of the key elements in this respect. Having a studio was important to all producers for their sound, except Bauerfeind. He relied on rented studios throughout his career because this gave him and his clients flexibility in combining certain sounds. Moreover, working with high-profile clients has ensured the budget to pay for the luxury of sonic details or a nostalgic feel. For example, Bauerfeind is recording Helloween's current album with a completely analogue chain of tape machines, 24 API equaliser units taken from an old mixing desk owned by Fleetwood Mac, and the recovered drum set of the late Helloween drummer Ingo Schwichtenberg 
(†1995). The band made these decisions against Bauerfeind's will, who would have preferred a more pragmatic system that allowed creative freedom in the mixing phase. This conflict once again shows the tension between the producers' desire to be free of restrictions and the common desire of German metal artists to pursue a more conservative production concept, even in the case of the formerly progressive Helloween.

An area with a clear generational difference is the role of studio acoustics, both in terms of importance and desired characteristics. In contrast to the younger ones, the veteran producers put a high value on acoustics. Bemm and Johns both had three versions of their own studios, and each was deliberately designed with a specific acoustics in mind. Bemm still fondly remembers the drum recordings in his second studio, a 700 square meter room in a former gym with $90 \mathrm{~cm}$ thick, tiled walls that created a hard and bright drum sound. Johns's two main versions of his studio also had tiled walls covered with a curtain to control reflections to create the explosive drum sound that thrash bands liked in the 1980s and ' 90 s. The similarities between the spatial qualities in the two important studios for early German metal may well be coincidental. Yet when Dennis Ward, founder of early German band Pink Cream 69 and high-profile metal music producer, was asked by Rock Hard whether there was a German metal sound, he emphasised the room acoustics as the only feature:

»Oh, indeed, there definitely is one [a German metal sound]. Just a few days ago, I got a request, one of the kind I often receive. The band was from Italy and they wanted me to make them sound like sall the great German metal bands . This probably is the best evidence. But I cannot explain what exactly makes up this sound given that Accept sound totally different from Helloween. There must be some common element. Maybe this kind of music from Germany is produced with more reverb, roomier and not so dry and sin your face as much of the music coming from the US« (Schiffmann 2018: 75; my translation).

For Bauerfeind, reverberated live rooms are highly important, which accords with the statements of Johns, Bemm and Ward. This preference is based on a larger production concept. Bauerfeind attempts to capture the »war-like« qualities of >Teutonic - metal that he sees in direct connection with Prussian marching music, which emphasises the drums as opposed to Scottish bagpipes or Scandinavian horns (see Herbst/Bauerfeind 2020).4 To support the drums

4 This view coincides with Wilhelm Reich's (1970: 350) claim that Prussian militarism contributed significantly to creating foreign images of Germans as »rigid, robotlike, war-machine automatons« (see also Nye 2012). 
and increase their perceived size, Bauerfeind would choose live rooms with hard reflections similar to those in Bemm's and Johns's studios.

»Rock'n' roll is not made in a nice country studio. ... There were plenty of metal studios in the '90s, whether it was Hansen or RA.SH Studio, all of which were in WWII bunkers. ... Especially in metal, these studios were so popular since you had a very special sound because, of course, a 6-meter reinforced concrete wall sounds different from any plasterboard wall. ... When I record in a shoebox [tiny recording room], it sounds like shoebox. When I record in a bunker with 6-meter thick walls, it sounds different. No chance of doing that anywhere else. I don't know how many records I recorded at Kai [Hansen]'s studio back then, or in RA.SH Studio« (Interview Bauerfeind 2019).

Creating this »war-like « drum sound also required certain drum tunings: extremely low in general and with a pronounced wire rattle on the snare (Herbst 2019b, 2020b). Younger producers take very different approaches to drum production. Levermann, for instance, is keen to improve the drummer's playing feel to capture the best performance, and he avoids tuning the drums too low, as his experience shows that this takes away the rebound required for fast drumming. Still, he has worked with drummers of the first wave of German metal who had recording experience with Bauerfeind and accepted playing with less playable tunings in favour of Bauerfeind's vision of a >Teutonic sound. Younger generations of drummers, however, would feel restricted by such tunings, so Levermann tunes the drums to support the player and moves the creation of the drum sound to the mixing phase. The drum sound is captured less in the recording alone, which modern producers generally accept, since samples are needed to reinforce or even replace the drums anyway, an approach to production that veteran producers do not like. The acoustics of the drum room, crucially important for the recording practices of the veteran producers, have become less important for many of the younger producers. Modern drum sounds tend to have quiet cymbals and loud shells, and so younger producers like Levermann and Lammert add samples with room characteristics to create depth and artificially increase size. Since these sounds may well come from sample libraries, there is little reference to physical acoustic spaces and their cultural associations, as it was and still is the case in Bauerfeind's productions. 


\section{Conclusion}

Labels in rock music that refer to geographical, cultural and historical associations of the music's origin have rarely been analysed from a production perspective. This chapter explored >Teutonic - metal, focusing on the generational effects of those producing the music. The findings reported in this chapter and in other outputs of the wider research project on >Teutonic metal (Herbst 2019b, 2020a, 2020b, 2020c) suggest that the early years of German metal were marked by experimentation, adopting stylistic and productional elements from the Anglo-American world, but with a German twist. Much metal from Germany sounded different than their international counterparts, either because it was progressive and was perceived as highly innovative, or extremely conservative through the use of simplistic riffs and stiff rhythms - a feature that is often mentioned in foreign media and by all producers (see Herbst 2019b, 2020c).

Today several generational differences are evident. Older bands like Helloween and Blind Guardian, who used to be original, innovative and progressive, have become nostalgic and proudly accept their image as >Teutonic metal bands. For some musicians it is even a way of life to be >Teutonic . Helloween have reunited and announced their upcoming world tour under the motto »United Alive World Tour Part II . It seems that the label >Teutonic<, which a few decades ago had a musical meaning with a specific production aesthetic, has become a form of nostalgia for bands and their older audience, but also for younger fans who celebrate key bands of German metal. Nowadays >Teutonic metal is mainly a business concept for record labels and production professionals who cater to the nostalgic desires of their clients and audience. Bauerfeind has created a sonic signature that he classifies as >Teutonic and for which he is repeatedly engaged by established German bands and newer artists who want to sound that way. Working according to his convictions has allowed him to make a living as a metal producer for over thirty years now. He has even deleted his professional website because he no longer needs to advertise his services. From the other two of the older generation, Johns has retired and produces only occasionally, whilst Bemm continues to produce mainly out of love for music. The newer generations of producers who have or are starting a business in the digital age, in which cultural associations have already largely disappeared in music production, face a different market situation. Their priority is to offer to their clients an impeccable service with the best possible flexibility while keeping costs under control. They do not claim that there is no >Teutonic s sound but mainly consider it a 
mythology that is outdated and unimportant for today's business. For them, the producer's heritage has no effect on the final product. Just as seminal 'Teutonic < bands such as Accept and Kreator nowadays have foreign producers like the British Andy Sneap and the Swedish Jens Bogren, they themselves enjoy an international clientele. In the globalised world, culture-specific production practices seem to have lost their purpose.

\section{Bibliography}

Adelt, Ulrich (2016). Krautrock. German Music in the Seventies. Ann Arbor: University of Michigan Press.

»A. K. « (1902). »Richard Strauss's >Feuersnot< in Berlin. «In: The Musical Times and Singing Class Circular 43 (718), pp. 808-809.

Anderson, Benedict (1983). Imagined Communities. London: Verso.

Anonymous (2013). »The Big Teutonic Four. Vereint im Hass. «In: Metal Hammer 6, pp. 50-51.

Barr, Tim (1998). Kraftwerk: From Düsseldorf to the Future (with Love). London: Ebury Press.

Barton, Geoff (1986). »Grave Digger - War Games. «In: Kerrang! 117, p. 8.

Brosnac, Donald (2004). The Amp Book. Westport: Bold Strummer.

Brown, Clive (1999). Classical \& Romantic Performing Practice 1750-1900. Oxford: Oxford University Press.

Brown, Andy R. / Spracklen, Karl / Kahn-Harris, Keith / Scott, Niall W.R. (Eds.) (2016). Global Metal Music and Culture. Current Directions in Metal Music. London: Routledge.

Burns, Robert (2008). »German Symbolism in Rock Music. National Signification in the Imagery and Songs of Rammstein. «In: Popular Music 27 (3), pp. 457-472.

Cohen, Anthony (1985). The Symbolic Construction of Community. London: Travistock.

Dome, Malcolm (1986). »The Red Brigade.«In: Kerrang! 117, pp. 24-29.

Elflein, Dietmar (2017). »Restless and wild. Early West German heavy metal.« In: Perspectives on German Popular Music. Ed. by Michael Ahlers and Christoph Jacke. London: Routledge, pp. 116-122.

Everley, Dave (2001). »Germanic Street Preachers. «In: Kerrang! 847, pp. 44-45.

Fortnam, Ian (1998). »Nude Power Generation.«In: Kerrang! 726, pp. 40-42.

Heavyocity Media (2019). »Damage«, https://heavyocity.com/product/damage (access: 31 December 2019).

Heesch, Florian (2010). "Metal for Nordic Men? Amon Amarth's Representation of Vikings«. In: The Metal Void: First Gatherings. Ed. by Niall W. R. Scott and Imke v. Helden. Oxford: Inter-Disciplinary Press, pp. 71-80.

Heesch, Florian (2014). »Nordisch - Germanisch - Deutsch? Zur Mythenrezeption im Heavy Metal. «In: Typisch Deutsch: (Eigen-)Sichten auf populäre Musik in diesem unserem Land. Ed. by Dietrich Helms and Thomas Phleps (= Beiträge zur Popularmusikforschung 41). Bielefeld: transcript, pp. 127-151.

Henderson, Paul (1989). »Thunderhead Concert Review Theaterfabrik Munchen. «In: Kerrang! 260, p. 48.

Henderson, Paul (1990). »Running Wild - Death or Glory.« In: Kerrang! 275, p. 26. 
Herbst, Jan-Peter (2017). »Historical Development, Sound Aesthetics and Production Techniques of the Distorted Electric Guitar in Metal Music. « In: Metal Music Studies 3 (1), pp. 23-46.

Herbst, Jan-Peter (2019a). »Old Sounds with new Technologies? Examining the Creative Potential of Guitar >Profiling - Technology and the Future of Metal Music from Producers' Perspectives. «In: Metal Music Studies 5 (1), pp. 53-69.

Herbst, Jan-Peter (2019b). »The Formation of the West German Power Metal Scene and the Question of a >Teutonic - Sound.« In: Metal Music Studies 5 (2), pp. 201223.

Herbst, Jan-Peter (2020a). »From Bach to Helloween. >Teutonic S Stereotypes in the History of Popular Music. «In: Metal Music Studies 6 (1), pp. 87-108.

Herbst, Jan-Peter (2020b). "Sonic Signatures in Metal Music Production. Teutonic vs British vs American Sound.«In: Samples 18, pp. 1-26.

Herbst, Jan-Peter (2020c). »German Metal Attack. Power Metal in and from Germany. «In: Made in Germany. Ed. by Oliver Seibt, David-Emil Wickström, and Martin Ringsmut. London: Routledge, pp. 81-89 (forthcoming).

Herbst, Jan-Peter / Bauerfeind, Karl (2020). »Teutonic Metal. A Production Perspective on Nationality and Culture in Metal Music's Sound and Performance. «In: So far, so good... so what? Approaching the Metal Realities. Ed. by Florian Heesch and Reinhard Kopanski. Bielefeld: transcript (forthcoming).

Hill, Robert (1994). » Overcoming Romanticism $<$ : On the Modernization of TwentiethCentury Performance Practice. "In: Music and Performance during the Weimar Republic. Ed. by Bryan Gilliam. Cambridge: Cambridge University Press, pp. 3758.

Hobsbawm, Eric / Ranger, Terence (1992). The Invention of Tradition. Cambridge University Press: Cambridge.

Johnson, Howard (1986). "Scorps get set to scorch.«In: Kerrang! 126, p. 28.

Johnson, Howard (1987). »Destruction: Release From Agony.«In: Kerrang! 167, p. 12.

Kahnke, Corinna (2013). „Transnationale Teutonen. Rammstein Representing the Berlin Republic. «In: Journal of Popular Music Studies 25 (2), pp. 185-197.

Karjalainen, Toni-Matti (2018). Sounds and Origin in Heavy Metal Music. Newcastle: Cambridge Scholars Publishing.

Kerr, Anne / Wright, Edmund (2015). »Teutons. « A Dictionary of World History. Oxford: Oxford University Press ( $3^{\text {rd }}$ ed.), p. 655.

La Rocca, Francesco (2017). »The Viking Raids of England in Metal Music: From Ideology to Parody.« In: Metal Music Studies 3 (2), pp. 219-229.

Lawson, Colin / Stowell, Robert (1999). The Historical Performance of Music. An Introduction. Cambridge: Cambridge University Press.

LSD-Studio (2020). »Studio«, http://www.lasselammert.com/studio.php (access: 6 January 2020).

Lusty, Heather (2020). »Heavy Metal Microgenres. «In: The Microgenre. A Quick Look at Small Culture. Ed. by Molly C. O'Donnell and Anne H. Stevens. New York: Bloomsbury, pp. 163-170.

Martin, Adam (2014). The Role and Working Practice of Music Producers: An Interpretative Phenomenological Analysis. PhD thesis, University of Hull.

Massey, Howard (2015). The Great British Recording Studios. Milwaukee: Hal Leonard.

Meintjes, Louise (2003). Sound of Africa!: Making Music Zulu in a South African Studio. Durham: Duke University Press. 
Nye, Sean (2012). »What is Teutonic? - An Update on the German Question«. In: Böse Macht Musik. Zur Ästhetik des Bösen in der Musik. Ed. by Katharina Wisotzki and Sarah R. Falke. Bielefeld: transcript, pp. 113-129.

Nye, Sean (2013). Teutonic Time-slip: Travels in Electronic Music, Technology, and German Identity, 1968-2009. PhD thesis, University of Minnesota, http://hdl. handle.net/11299/151315 (access: 9 June 2020).

Otto, Dennis (2013). »Review: The Big Teutonic Four«, https: / /www.metalinside.de/ review/the-big-teutonic-four/the-big-teutonic-four (access: 9 June 2020).

Owsinski, Bobby (2006). The Mixing Engineer's Handbook. Boston: Thomson Course Technology.

Owsinski, Bobby (2008). The Audio Mastering Handbook. Boston: Thomson Course Technology.

Pichler, Peter (2017). »The Power of the Imagination of Historical Distance: Melechesh' >Mesopotamian Metal as a Musical Attempt of Solving Cultural Conflicts in the Twenty-First Century. «In: Metal Music Studies 3 (1), pp. 97-112.

Pumpkin TV (2019). »Kai Hansens Update aus dem Studio«, https://www.youtube. com/watch?v=IRH1J7aHOkU (access: 31 December 2019).

Reich, Wilhelm (1970). The Mass Psychology of Fascism. Ed. by Mary Higgins and Chester M. Raphael. New York: Farrar, Straus and Giroux.

Russell, Xavier (1986). »Kreator - Pleasure to Kill.«In: Kerrang! 118, p. 22.

Russell, Xavier (1991). »Udo \& Rage concert review. «In: Kerrang! 342, p. 54.

Schiffmann, Andreas (2018). »Dennis Ward«. In: Rock Hard 8, pp. 74-75.

Schürer, Petra (2009). »Teutonischer Tod«. In: Metal Hammer 06/2009, p. 6.

Segal, David (2001). »Heavy-Metal Rammstein Stakes Its Claim to Flame. «In: Washington Post, 30 July, https://www.washingtonpost.com/archive/lifestyle/2001/ 07/30/heavy-metal-rammstein-stakes-its-claim-to-flame/390e2c05-ea45-4b18a837-a16f511b5b32 (access: 9 June 2020).

Smith, Jonathan (1996). »Beyond the Divide Between Cognition and Discourse: Using Interpretative Phenomenological Analysis in Health Psychology. «In: Psychology of Health 11 (2), pp. 261-271.

Stappert, Andreas (2004). »UDO. Die Rente kann warten«. Rock Hard 6, p. 92.

Stent, Elliot (2019). »British vs. American Amps - Which Sound Better?«. In: Andertons Music, https://blog.andertons.co.uk/learn/british-vs-american-amps (access: 31 December 2019).

STL Tones (2019. "Lasse Lammert «, https://www.stltones.com/collections/lasselammert (access: 29 December 2019).

Thomas, Niall (2015). The Development of Technology and its Influence on Recorded Heavy Metal Music 1969-2015. PhD thesis, University of Hull.

Van der Kirkhoff, W. (1993). »Accept - Objection Overruled.«In: Kerrang! 429, p. 21. von Helden, Imke (2015). Norwegian Native Art: Cultural Identity in Norwegian Metal Music. Zürich: LIT.

Wallach, Jeremy / Berger, Harris M. Berger / Greene, Paul D. (Eds.) (2011). Metal Rules the Globe. Heavy Metal Around the World. Durham: Duke University Press.

Watts, Chris (1990). »Victory - Temples of Gold.«In: Kerrang! 316, p. 26.

Weichert, Maik (2015). »German Metal? German Metal!« In: Rock Hard 11, p. 14.

Williams, Vaughan (2008 [1932]). »Weber, Der Freischütz overture. «In: Vaughan Williams on Music. Ed. by David Manning. Oxford: Oxford University Press, pp. 415416.

Zagorski-Thomas, Simon (2012). »The US vs the UK Sound. Meaning in Music Production in the 1970s. " In: The Art of Record Production. An Introductory Reader for 
a New Academic Field. Ed. by Simon Frith and Simon Zagorski-Thomas. Farnham: Ashgate, pp. 57-76.

\title{
Discography
}

Accept (2010). »Teutonic Terror.« On: Blood of the Nations. Nuclear Blast 2605-1. Rock Hard (1987). Teutonic Invasion Part One. Road Runner 9624.

Rock Hard (1988). Teutonic Invasion Part Two. Road Runner 9546-1.

Running Wild (1989). Death or Glory. EMI Noise CDP 7933242.

Sargant Fury (1991). Still Want More. WEA 9031-75188- 2.

Thunderhead (1989). Behind the Eight-Ball. Intercord INT 145.122.

Various (2013). The Big Teutonic Four. Nuclear Blast 3035-1.

Victory (1990). Temples of Gold. Metronome 843 979-1.

\section{Interviews}

Bauerfeind, Karl (2017). Gefrath, 25 July.

Bauerfeind, Karl (2019). Hamburg, 20 November.

Bemm, Siegfried (2017). Hagen, 27 July.

Johns, Harris (2018). Berlin, 15 August.

Lammert, Lasse (2018). Lübeck, 5 February.

Levermann, Sebastian (2019). Arnsberg, 18 November.

\begin{abstract}
Labels that denote a cultural or regional characteristic are common in the metal music discourse. Based on interviews with five internationally renowned German metal producers, this chapter explores the views of these professionals on the 'Teutonic - metal label, examining what it means to them and how it may influence their practices. The study concentrates on selected areas of production such as systematic recording approaches, choice of equipment and studio acoustics with a focus on generational effects, comparing three important producers from the early years of German metal with two younger producers of international standing. The findings suggest an incoherent use and multiple connotations of the sTeutonic < metal label. While in the early years it was disparagingly used by foreign media and thus avoided by the German press and German artists, over time it has become a marker for a style of traditional heavy and thrash metal and a marketing term with which record labels and bands serve their own nostalgic longings and those of their fans. One of the veteran producers proudly describes himself as a >Teutonic - metal producer, an image upon which his career is built, and another seasoned producer, although not
\end{abstract}


convinced by stylistic labels, has benefitted from them throughout his career. Even though the younger producers acknowledge the achievements of the producers of the first wave of German metal, they believe that national and cultural characteristics are outdated in today's global metal music industry. For them regionally or culturally associated sonic signatures are relics of the past, since international, remote collaboration is the norm today and music is produced with a standard set of (often digital) tools. 